|明らかにされている。

著者は、強し相互性の影の側面、すなわち 「身内」同士の協力という名の下で「よそ者」に 敵意を示す傾向についても分析している。「グ ループ内で協力関係があると、そのグループの 人間がグループ外の人間に対して、殺人を行う ほど攻撃的になることがある」と記す。また、 複数の赤の他人を組織的に殺害する行為は、 人間社会で頻繁に起こっており、これを「例外
的、病理的、あるいは精神障害と説明するこ とはできない」と続ける。そして著者は、「ア ダム・スミスが物々交換("truck, barter and exchange")』と巧妙に説明した人間の性癖 は、それと対抗関係にある『奪取、脅迫、強要 ("take, bully, and extort")』への誘惑と常に居 心地の悪い共存を続けてきた」と結論づける。

本書はとても読みやすく、幅広い読者層が 期待できる。ただし、詳しい記述が不足して
おり、正式なモデル構築や詳細な分析的論証 を避けている。そのため本書は、動的に進化 するシステムとしての経済に関心を抱く人々 にとっての、この分野への足がかりとしての 意味をもつにとどまるだろう。

評者の Herbert Gintis は、サンタフェ研究所に 所属し、マサチューセッツ大学 (University of Massachusetts, 15 Forbes Avenue, Northampton, Massachusetts 01060, USA）の名誉教授で ある。

\title{
essay concepts
}

\section{究極の「時」をもとめて}

時間:どれほどの宇宙論的な時間スケールを我々は制御し、利用しているのだろう？

\section{Alexander E. Kaplan}

「耳されやすい力モは分刻みで生まれて 而州くる」とは、米国の興行師、P.T. Barnum の言葉だ。力モの新生児を数えてゆ くのも、時間を測る良い方法かもしれない。た だし、分と比べたら、秒の方が大事だろう。な にしろ、我々の心臓の鼓動はほぼ 1 秒の長さ なのだ。だが、この秒というスケールも、測る ものによっては、帯に短し襩に長し、という ことになる。ビッグバン理論によれば、我々 の宇宙の年齢は約 140 億年で、秒に換算する と $5 \times 10^{17}$ 秒だ。量子宇宙論の究極の時間ス ケール(プランク時間)は、ビッグバン誕生の 閃光の長さで約 $10^{-43}$ 秒、これは、時間の根 本的な「最小単位」とみなすことができる。そ れより短くなると、四次元の時空からなる通 常の物理現象は、「超ひも理論」の仮説のよう に、さらに多くの次元へと分かれる可能性が ある。

対数のアタマに切り替えてみれば、ほぼ70 年(およそ $2 \times 10^{9}$ 秒) という寿命をもつ我々 は、プランク時間よりも、宇宙の年齢に近い スケールで生きている。（訳注：対数関 数は10の何乗、の「何乗」の部分を取 り出してくる。いいかえると「桁」 を見る関数である。だから、対 数のスケールでは、宇宙は 約17歳、プランク時間は

NATURE月刊ダイジェスト|11月号
マイナス43歳、人間の寿命は 9 歳という勘定 になる。我々は長いこと、時間の経過を追う 方法を学んできた。「時間的人間」(Homo temporal) と呼んでも過言ではない。しかし、 我々はその時間のどれくらいを制御し利用し ているだろうか？ その「長い方」のスケール は未だアカデミック世界での話に留まってい るが、「短い方」はいまや活気あふれる科学と 技術の前線に躍り出てきた。その最もわかり やすい例が、情報伝達とコンピューターであ る。さらに高度なコンピューター演算をめざ す際の、主な指標の 1 つがクロック周波数、 あるいはその逆数のクロック周期だ。私の研 究室の片隅には、1989年型UNIXコンピュー

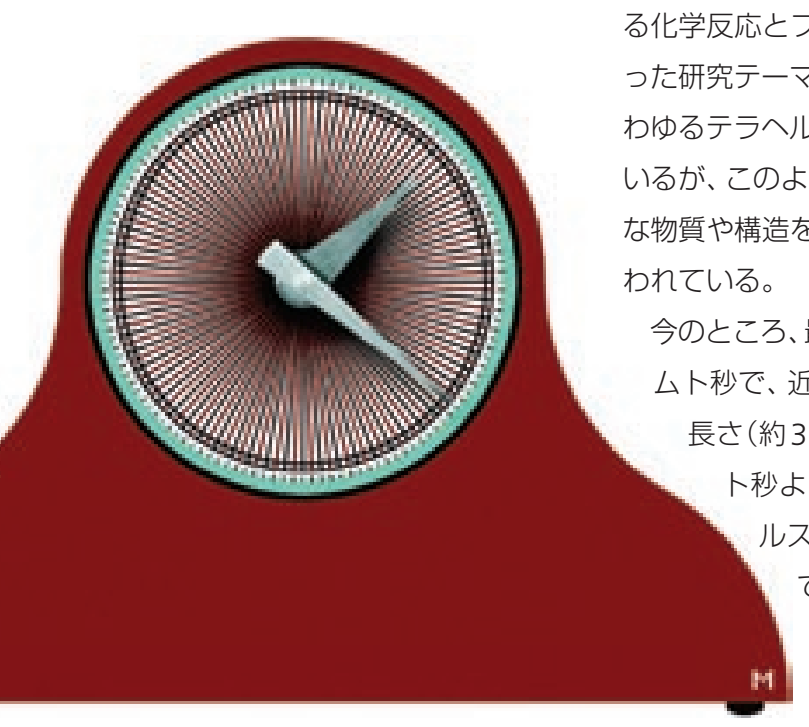

ターの遺物があるが、そのクロック周波数は

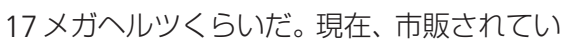
るコンピューターのクロック数は 3 ギガヘル ツ、つまり0.3ナノ秒 $\left(10^{-9}\right.$ 秒)に達している。

レーザーはさらに日進月歩で、より短い時 間領域に入ってきている。1959年にレ一ザー が発明されてからすぐに、光のパルスの長さ (持続時間)はナノ秒、さらにはピコ秒 $\left(10^{-12}\right.$ 秒)の閾值を越え、なおもより短いパルスを 求めて競争が繰り広げられている。ピコ秒以 下やフェムト秒 $\left(10^{-15}\right.$ 秒)の領域は研究の宝 庫亡なっており、超高速プロセスの記録、時 間分解分光法、ピコ秒より短い緩和時間をも つ半導体の開発、強力なレーザーパルスによ る化学反応とフェムト秒レベルでの制御とい つた研究テーマに事欠かない。この領域は、い わゆるテラヘルツ(10 12 ヘルツ)技術も擁して いるが、このようなパルスは、例えば、不透明 な物質や構造を「透視」する診断装置などに使 今のところ、最短レーザー記録は 4 ～5 フェ ム卜秒で、近赤外線しーザーの1周期分の さ(約3フェムト秒)に近い。1フェム 秒よりさらに短い、制御可能なパ レスを発生させる努力も続けられ ている。ゼうしてそんなに短く したいのか? 1 周期分よ り短いパルスの場合、そゅ 
>|の最も高いスペクトル周波数は、パルスの 長さ $\tau$ に比例するからだ。光子のエネルギー は周波数にプランク定数ちを掛けたものな ので、パルスの最も高い光子エネルギーは $\mathrm{E}_{\max } \approx \hbar / \tau$ と計算できる。ピコ秒以下からフ エムト秒の領域は、 $E \sim 0.1-0.01$ 電子ボルト (分子反応の典型的なエネルギースケール) に相当するが、0.15フェムト秒(150アト秒， $150 \times 10^{-18}$ 秒) 以下の領域は原子物理学の分 野だ(訳注：電子ボルト $(\mathrm{eV})$ は、電子 1 個を 1ボルトの電圧で加速したときのエネルギ一)。 これは、水素原子の基底状態にある電子が陽 子を一周するのにかかる時間だ。このような パルスを発生させる方法がいくつか提案さ れてきた。最近、高次の調和成分を使って、 フェムト秒より短いパルスが実験的に観測さ れた。このような 1 周期以下、あるいは 1 周 期ちょうどのパルスは、(電波から極紫外線領 域までの)きわめて広いフーリエスペクトル をもっていて、(黒体放射のような)標準的な 超広帯域の発生源から生じたパルスとは、著 しく異なる特性をもっている。理想的な条件 下では、スペクトル成分の全てが同じ位相に なるのだ。このようなスケールの大きい、ス ペクトルの境を踏み越えたコヒーレンスは、 通常の光学分野では決してお目にかかること ができない。実際、（例えば太陽光のように） 超短パルスは黒体放射に多く見られるもの の、それらはいつやって来るかわからないし、 どうふるまうかもわからない。ようするに完 全にランダムなので役に立たないのだ。パル スの世界では、パルスが足並み揃えてやって 来ること(=コヒーレンス) と、制御すること ができる、という点で、状況が一変する。

原子スケールの地平線のかなたに、重元素 のイオンが鎮座している。最も重い安定な原 子であるウランを例にとろう。ウランの周囲 の電子を 1 個だけ残して、残りの電子を身ぐ るみ剥いでしまった「極限のイオン」を思い浮 かべることができる。この最後の電子を取り 除くには、(ウランのK殼遷移に近い)110キロ 電子ボルトが必要で、これは、さらに短い時 間スケールの約 10-20秒を作り出す。それを 超えると、原子・イオン物理学は、「量子の砂 漠」へと迷い込んでゆく。なおも短くしてい くと、我々は、根元的な興味をもたらす次の 領域に遭遇する。量子電磁力学(QED)である。 電子の静止エネルギ一の2 倍のエネルギ一(約
1 メガ電子ボルト)を要する電子ー陽電子対 の生成や、強い核反応、たとえば 1.2 メガ電 子ボルトに近い陽子と中性子をつくる重水素 の電子壞変、といつた分野だ。このような現 象は、原子の光イオン化を彷佛とさせるが、 QEDでは、5桁以上も高いエネルギー・スケー ルが基準になっている。その時間スケールも ゼプト秒 $\left(10^{-21}\right.$ 秒)まで縮まる。核反応を解明 し、時間分解し、究極的には制御さえできる かもしれない、アト秒以下からゼプト秒まで のパルスを生成制御することが実現可能かど うかも、近年議論されてきた。その構想は、密 度の高い円周の中の自由電子に、現在可能な $10^{21} \mathrm{~W} / \mathrm{cm}^{2}$ という強度のレーザーを当てる ものだ。このような状態を「レーズトロン」 (lasetron) と呼ぶ。自由電子は、物質を構成し ているナノ粒子の大規模なイオン化ととも に、ほとんど瞬時に放出され、E〜 50 ×ガ電子 ボルト程度のエネルギーにまで加速される が、こうした電子は、QED や原子核の領域の 光子を生成できるに違いない。

この地平を過ぎると、我々は高エネルギー 物理学の領域へと踏み込む。そこでは、巨大 な加速器の中で、ほとんど光速に近づいた荷 電粒子が、標的核(または逆向きに進んでくる
粒子) と衝突し、新しい素粒子の雲を生み出 す。いつの日か、こうした衝突による粒子の 生成を、コヒーレントに制御する方法がみつ かったら、その放射は、これまでよりずっと 速いものになるだろう。たとえば 1 テラ電子 ボルト(100万メガ電子ボルト)の最も高い光 子エネルギーをもつパルスは、理想的な条件 下では、約 $10^{-27}$ という短さになるだろう。こ れでもまだ、究極の時間スケール、10 $10^{-43}$ 秒に は程遠い。だが、思い悩む必要などない。な にしろ、好奇心、いいかえると、あくなき探 究心という名のフル回転をつづけるエンジン に駆動され、我々は進み続けるにちがいない から。我々は、ようするに、騙されやすい力モ なのだ。

筆者の Alexander E. Kaplan は、ジョンズ・ホプ キンズ大学の電気・コンピューター工学部 (the department of Electrical and Computer Engineering, Johns Hopkins University, Baltimore, Maryland 21218, USA)に所属している。

\section{FURTHER READING}

Paul, P. M. et al. Science 292, 1689 (2001).

Hentschel, M. et al. Nature 414, 509 (2001).

Zewail A. Nature 412, 279 (2001).

Kaplan, A. E. \& Shkolnikov, P. L. Phys. Rev. Lett. 88, 74801 (2002).

Greene, B. The Elegant Universe, (Random House, New York, 2003).

\section{news and views}

\section{宇宙鉝物学：よその太陽系の鹿}

\section{Steve Desch}

塵の円盤で取り囲まれている恒星は、形成中の太陽系なのかもしれない。塵か ら放射される光の解析から、恒星の周りを回っている彗星あるいは微惑星、さら には惑星までもがここに存在する可能性がでてきた。

\section{原文：Dust in another solar system}

Nature Vol.431(636-637)/ 7 October 2004; www.naturejpn.com/digest

들 宙鉱物学とは、天文学と鉱物学が組み 合わさった新たな分野である。主に中 間赤外線(MIR)の波長域(2 $30 \mu \mathrm{m})$ での天 体観測によって、多くの場合は原始星のまわ りにある、宇宙の塵粒子の大きさ、結晶構造、 化学的構造を確定することを目的とする。こ のような観測で、原始惑星系の円盤における
塵の分布について多くのことが明らかにされ る。塵の構造と進化の過程、そして新たに形成 されつつある太陽系の岩石物質、つまり最終 的に地球のような惑星を形作る物質につい て、詳しく調べられるのだ。赤外線の検出に おけるかなりの技術的進歩が必要であったた め、宇宙鉱物学的な観測が可能になったのは » 